\title{
Cluster Analysis of Food Consumption Patterns among Women of Reproductive Age in Indonesia
}

\author{
Wardina Humayrah $^{1^{*}}$, Hardinsyah ${ }^{2}$, Ikeu Tanziha ${ }^{2}$, Umi Fahmida ${ }^{3}$ \\ ${ }^{1}$ Nutrition Study Program, Food Technology and Health Faculty, Sahid University, \\ Jakarta, 12870, Indonesia \\ ${ }^{2}$ Department of Community Nutrition, Faculty of Human Ecology, IPB University, Bogor 16680, Indonesia \\ ${ }^{3}$ Southeast Asian Ministers of Education Organization Regional Centre for Food and Nutrition \\ (SEAMEO RECFON), University of Indonesia, Jakarta 10430, Indonesia
}

\begin{abstract}
The aim of this study was to cluster the provinces based on the Food Consumption Patterns (FCP) of the Women of Reproductive Age (WRA). This study used secondary data from the 2014 Indonesia Total Diet Study conducted by the Ministry of Health Indonesia. The final subjects included 40.954 healthy WRA aged 15-49 years old. FCP was calculated based on energy adequacy of WRA of nine major food groups for each province. The hierarchical clustering with Ward's method was applied to cluster the FCP of WRA. The results showed that three clusters of FCP were found. The first cluster was characterized by higher intake of cereals and animal foods, but lower intake of tubers, vegetables, and fruits, which implies a high risk of vitamin B6 and C deficiencies. The second cluster was characterized by higher intake of pulses, oil and fat, oily seeds, and sugar, but lower intake of vegetables and fruits as well as animal source foods, which implies high risk in vitamin B1, B3, and B12 deficiencies and overweight. The third cluster was characterized by higher intake of tubers, fruits, and vegetables but lower intake of animal sources foods, pulses, added fat and oily seeds, which implies a high risk in animal protein, fat, calcium, iron, vitamin B2, and folic acid deficiencies.
\end{abstract}

Keywords: food clustering, food consumption patterns, Indonesia, nutrient intake, women of reproductive age

\section{INTRODUCTION}

Women of Reproductive Age (WRA) are one of the important target groups in nutrition improvement and fulfillment before and during pregnancy (Lassi et al. 2015; Branca et al. 2015). According to the reports of Indonesia Basic Health Research in 2013,37\% of pregnant women and $23 \%$ of WRA had anemia. In addition, more than $20 \%$ of pregnant women and WRA are at high risk of chronic energy deficiency $(\mathrm{MoH}$ 2013). Total Diet Study also reported that more than $80 \%$ of pregnant women and WRA had inadequate energy intakes and more than $50 \%$ of them had inadequate protein intake (MoH 2014).

Previous studies revealed that Food Consumption Patterns (FCP) of Indonesian WRA were less diverse and low in quality, which were indicated by the high intake of cereals but low intake of animal source foods, vegetables, and fruits (Rahmawati 2015; Perdana 2014). Where as dietary pattern diversity reflects nutrition quality of the diet which affects nutritional status (Hardinsyah 2007).
The FCP of Indonesian varies among regions and ethnicities which influenced by culture, belief, religion, and socio-economic status (Situngkir 2015; Hines 2013; Civitello 2011). Thus cluster studies allowing for the classification of diverse FCP of Indonesian WRA could help nutrition program managers and policy makers in identifying the appropriate interventions for food and nutrition development of WRA (MoH 2016; FAO 2006). The presence of national food consumption data with total diet approach could possibly be examined for this study. Therefore, this study aimed to cluster the provinces with relatively similar FCP into several clusters and analyze WRA's nutritional adequacy levels according to the clusters.

\section{METHODS}

\section{Design and subjects}

This study used the data from the TDS in 2014, which was one of national individual food intake surveys conducted by National Institute of Health Research and Development, Ministry of

\footnotetext{
"Corresponding Author: tel: +6285606124307, email: wardina_humayrah@usahid.ac.id
} 
Health, Republic of Indonesia (NIHRD-MoHRI) using cross-sectional design. The inclusion criterion of this research subjects was WRA aged 15-49 years with healthy condition (subject perception). After exclusion and data cleaning (food item consumed $\leq 2$ types and energy intake $>400 \%$ energy adequacy level), thus final subjects was $40,954(98.50 \%)$.

\section{Data collection}

Individual Food Consumption Survey (IFCS) part of TDS was the first national-scale survey in Indonesia that collected individual consumption data completely. This survey was held by NIHRD-MoHRI and conducted in collaboration with various universities, Statistics Indonesia, Provincial, and District Health Offices, and technically assisted by the World Health Organization (WHO) and Institute Life Science International (ILSI). The implementation of IFCS is fully funded by the Government of Indonesia. IFCS had study sites in all provinces of Indonesia with 162,044 subjects from 46,238 households in 2,072 census blocks. In each census block, there were 25 chosen households. All the members in the household were interviewed and measured for the body weight, that was done by the trained nutrition personals.

The main data of this study were obtained from NIHRD-MoHRI in the form of electronic files which consisted of subject code, health status, physiological conditions, marital status, employment status, education, economic quintiles, food code, food types, and total food intake in grams. The 24-hours recall with 5-step multiple passes was applied for the food consumption data collection and it was validated with the repeated recall in 10 percents of sub-sample on the nonconsecutive days. Repeated measurements on this non-consecutive day were intended to observe if there were any food variations between days.

\section{Data analysis}

The entire data processing and analysis used 2007 Microsoft Excel and IBM SPSS version 22. The daily energy adequacy was used as the input value in the analysis. This approach was the most commonly used in clustering study to cluster FCP (Bailey et al. 2006). The energy content of foods was processed into energy adequacy as a percentage and then classified into nine food groups, i.e. cereals, tubers, animal source foods, oil and fat, oily fruits and seeds, pulses, sugar, fruits and vegetables, and others. The energy adequacy of each subject was aggregated into province level as the final input for the analysis.

The cluster analysis technique chosen was Hierarchical Clustering Ward's Method (HCWM) with the agglomerative concept. This clustering method is suitable for the data that have high heterogeneity (Latifa 2016; Babu et al. 2014; Everitt et al. 2011). This HCWM produced the province clustering in the form of dendrogram that showed the possibility of several numbers of clusters. Selection of the best number of clusters was validated by the ratio of standard deviation within clusters $(\mathrm{Sw})$ to standard deviation between clusters $(\mathrm{Sb})$ (Mattjik \& Sumertajaya 2011; Santoso 2010).

After the number of the best cluster was obtained, the characteristic type of each cluster was described through the comparison of mean intake of food groups (g/individual/day) between clusters. Then, the Kruskal Wallis and Mann Whitney tests were performed to identify differences in mean intake of food groups between clusters. The position of food groups domination among each cluster was visualized by Biplot. In addition, the nutrient intake levels of the subjects and the top three food sources of macro- and micronutrients in each cluster were also analyzed descriptively.

The macronutrient content of each food was calculated based on Indonesian Food Composition Table from Indonesian Nutrition Association (Persagi 2013), while some of the micronutrients such as calcium, iron, zinc, vitamin $\mathrm{C}, \mathrm{B} 1, \mathrm{~B} 2, \mathrm{~B} 3, \mathrm{~B} 6$, folate, $\mathrm{B} 12$, and $\mathrm{A}$ were completed from borrowed FCT at http:// fao.org/infoods (FAO 2013). The borrowed FCT considered the genetic relationship (species, family, or genus food's name) and water contents. The nutrients content of food products were taken from nutrition facts on the packaging that converted into $100 \mathrm{~g}$ edible portion.

The adequacy of macronutrients was calculated from daily intakes of each nutrient compared to individual nutrient requirements. The energy adequacy formula used Henry Equation (Henry 2005) while protein, carbohydrate, and fat adequacy were based on Hardinsyah et al. (2012). Since there were no individual requirements of vitamins and minerals, their adequacies used the approach from The Reference Nutrient Intake (RNI) by WHO/FAO (2004). The categories of adequacy level for macronutrients were based on Ministry of Health Indonesia (2014) while for micronutrients were based on Gibson (2005). 


\section{RESULTS AND DISCUSSION}

\section{Province clustering}

The total number of three cluster was considered best number as indicated by the ratio of standard deviation within clusters $(\mathrm{Sw})$ to standard deviation between clusters $(\mathrm{Sb})$ calculation. A group of provinces in each cluster formed an adjacent region. The Cluster- 1 was in the western region of Indonesia while Cluster-2 tend to be in the middle-south region, and Cluster-3 was in the eastern region of Indonesia (Figure 1). The Cluster-1 group had the largest member of provinces, consisting of Aceh, North Sumatera, West Sumatera, Riau, Jambi, Riau Islands, Bengkulu, South Sumatera, Lampung, West Kalimantan, South Kalimantan, Central Kalimantan, East Kalimantan, West Sulawesi, South Sulawesi, Central Sulawesi, Southeast Sulawesi, Gorontalo, West Nusa Tenggara, and Bali. The Cluster-2 group consisted of Banten, Special Region of Yogyakarta, Special Capital Region of Jakarta, West Java, Central Java, East Java, and Bangka Belitung Islands. The eastern region of Indonesia formed Cluster-3, consisting of North Sulawesi, Maluku, North Maluku, West Papua, Papua, and East Nusa Tenggara.

Based on the socio-demographic distribution, most of the subjects in the three clusters were $30-49$ years old $(>60 \%)$, in nonpregnancy $(>95 \%)$, married $(>70 \%)$, graduated from primary $(>40 \%)$ and junior high school $(>50 \%)$. Most of the subjects in clusters 1 and 2 were unemployed (include homemaker), while the majority of subjects in cluster-3 were working women. Most of the subjects $(50 \%)$ in clusters 1 and 3 belonged to a large family, while the majority of subjects in cluster-2 (>55\%) belonged to the small family. Subjects living in rural areas in cluster-3 was higher $(70 \%)$ than subjects in clusters 1 and 2. WRA in the provinces in cluster-3 tended to be more socially and economically disadvantaged than the other two clusters. This was inline with Dachlan and Suhab (2014) study which explained that most of the provinces in cluster 3 were located in Eastern Region of Indonesia (ERI).

According to Dachlan and Suhab (2014), Indonesia is divided into two regions consisting of Eastern Region of Indonesia (ERI) and Western Region of Indonesia (WRI). The ERI is a less developed region characterized by to the WRI. Even most of the poor provinces in Indonesia are mostly found in this region. This position has hardly changed significantly in the last 30 years. This backwardness is influenced by many factors, such as the lack of basic infrastructure, the low quality of human resources, education, and health, as well as poor regional connectivity, which trigger the soaring of the logistic cost that leads to low quality of life.

\section{Food consumption patterns}

The energy adequacy is fundamental food functions for overall body activities of human metabolism (Hargrove 2006). Therefore, the Food Consumption Patterns (FCP) of WRA were clustered based on individual percentage of energy intake and described in daily quantity $(\mathrm{g})$ of each food per capita between three clusters (Tabel 1). The FCP of WRA in Cluster-1 are dominated by cereals and animal source food groups compared to Clusters-2 and 3 (Table 1). WRA in Cluster-2 tended to have higher intakes

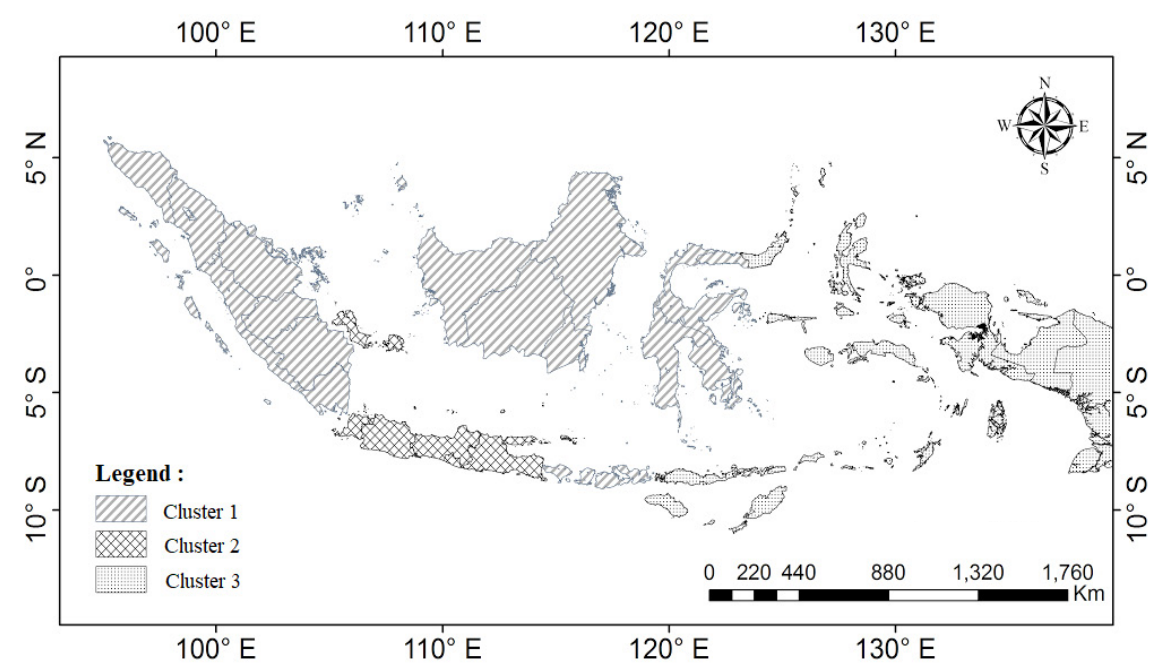

Figure 1. Map of Food Consumption Patterns of Women of Reproductive Age in three clusters 
Humayrah et al.

Table 1. WRA food groups daily intake per capita consumed in three clusters

\begin{tabular}{lcccc}
\hline \multirow{2}{*}{ Food groups } & Cluster-1 & Cluster-2 & Cluster-3 & \multirow{2}{*}{ p } \\
\cline { 2 - 4 } & Mean \pm SD $(\%)$ & Mean \pm SD $(\%)$ & Mean \pm SD $(\%)$ & $<0.0001$ \\
Cereals & $264 \pm 120(100)$ & $236 \pm 113(100)$ & $205 \pm 124(91)$ & $<0.0001$ \\
Tubers & $17 \pm 64^{\text {ab }}(19)$ & $22 \pm 56^{\text {ba }}(39)$ & $144 \pm 354(29)$ & $<0.0001$ \\
Animal source foods & $183 \pm 152(92)$ & $122 \pm 132(81)$ & $148 \pm 166(68)$ & $<0.0001$ \\
Oil and fat & $18 \pm 16(91)$ & $23 \pm 16(97)$ & $14 \pm 16(77)$ & $<0.0001$ \\
Oily seeds & $19 \pm 47(34)$ & $19 \pm 45(42)$ & $12 \pm 42(20)$ & $<0.0001$ \\
Pulses & $26 \pm 64(30)$ & $80 \pm 93(74)$ & $13 \pm 56(15)$ & $<0.0001$ \\
Sugar & $13 \pm 18^{\text {ac }}(62)$ & $14 \pm 21(73)$ & $12 \pm 17^{\text {ca }}(60)$ & $<0.0001$ \\
Fruits and vegetables & $121 \pm 120^{\text {ac }}(97)$ & $114 \pm 108(97)$ & $133 \pm 153^{\text {ca }}(93)$ & $< \pm 7(94)$ \\
Others (condiments) & $9 \pm 13(99)$ & $10 \pm 13(99)$ & 50001 \\
\hline
\end{tabular}

SD: Standar Deviation; a,b,c no difference between two clusters, using Mann Whitney test; $p<0.05$, significantly differences between three clusters using Kruskall Wallis test

of oil and fat, oily seeds, pulses, and other foods than the other two clusters. Meanwhile, WRA in Cluster-3 had the highest intakes of tubers, fruits and vegetables compared to Clusters- 1 and 2 .

The results of this study were in line with the study of Prihatini and Jahari (2010), which showed that almost all of the provinces in Cluster-1 had the calorie intake from animal source foods and cereals exceeding the national level. Meawnhile, Indonesian Ministry of Agriculture (2016) reported that the trend of intakes of tubers, fruits and vegetables in 20092015 among provinces in Cluster-3 was higher than the other provinces from Cluster-1 and 2. Food Security Agency of Republic of Indonesia (MoA 2015) has established a distinct FCP indicator for ERI, because intake of tubers as staple food subtitute in this region contributes to 9-30\% of the Recommended Dietary Allowance (RDA) for energy is higher compared to $6 \%$ at the ideal level and $2 \%$ at the national average level.

Meanwhile, high intake of pulses in Cluster-2 compared to Clusters- 1 and 3 was consistent with the previous studies. According to Cahyaningsih (2008), Central Java Province was a province that has a higher percentage of protein intake from pulses (i.e. tempe and tofu) than animal source foods. Intake of pulses in people of East Java and Central Java is the second highest among other provinces in Indonesia from 2009 to 2015 (MoA 2016). Then, the Province of Bangka-Belitung had the largest number of Javanese migrants and a significant number of Chinese ethnics who had lived for generations (Mulyana \& Zubair 2015; Arifin et al. 2015). Both of tempe and tofu were popular food for most of Javanese and Chinese because they were cheap and nutritious (Ren et al. 2011; Shurtleff \& Aoyagi 2011; Purwadaria et al. 2016).

Furthermore, the description regarding intakes of nine food groups was visualized according to each cluster region using biplot. Biplot can describe characteristics of each cluster group and the association between the food groups according to the position of cluster region (Figure 2). The biplot graph shows that the three

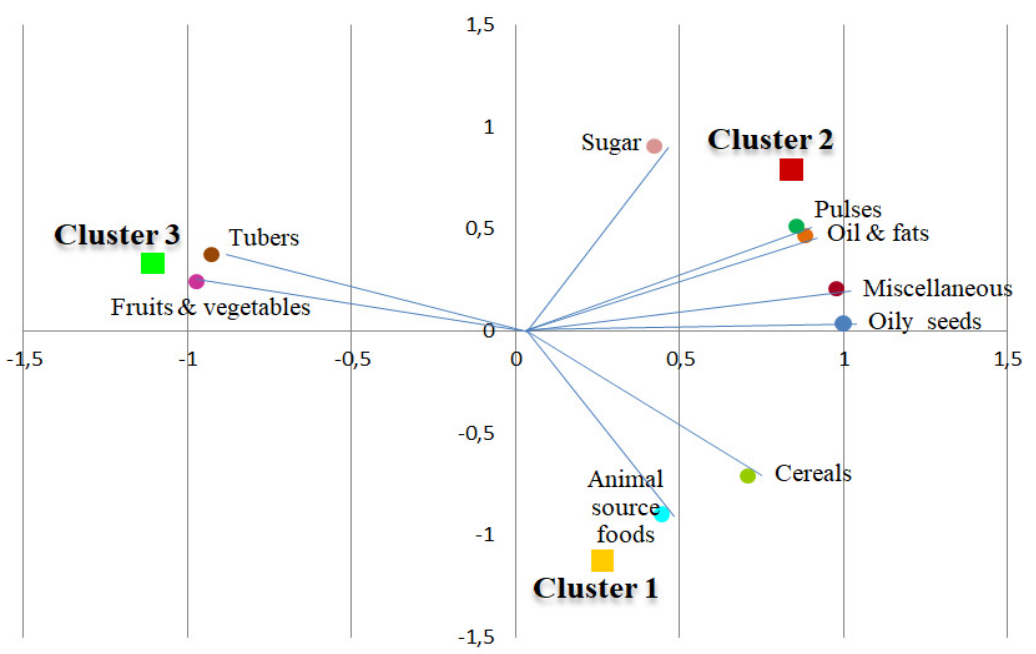

Figure 2. Biplot of FCP in three clusters 
Table 2. Nutrient intake and adequacy level among WRA in three clusters

\begin{tabular}{|c|c|c|c|c|}
\hline \multirow{2}{*}{ Nutrients } & Cluster-1 & Cluster-2 & Cluster-3 & \multirow[b]{2}{*}{$\mathrm{p}$} \\
\hline & Mean $\pm \mathrm{SD}(\%)$ & Mean $\pm \mathrm{SD}(\%)$ & Mean \pm SD(\%) & \\
\hline Energy (kcal) & $1603.4 \pm 616.8(105)$ & $1570.2 \pm 609.8(103)$ & $1446.7 \pm 588.1(96)$ & 0.00 \\
\hline Protein $(\mathrm{g})$ & $63.1 \pm 31.8(119)$ & $56.6 \pm 28.0(108)$ & $50.7 \pm 33.9(98)$ & 0.00 \\
\hline Fat $(\mathrm{g})$ & $46.3 \pm 32.6(91)$ & $53.0 \pm 29.6(105)$ & $30.7 \pm 26.7(61)$ & 0.00 \\
\hline Carbohydrate (g) & $236.8 \pm 95.3^{\mathrm{bc}}(104)$ & $220.9 \pm 90.7(97)$ & $239.9 \pm 110.3^{\mathrm{cb}}(107)$ & 0.00 \\
\hline Calcium (mg) & $342.5 \pm 433.1(28)$ & $352.4 \pm 314.2(29)$ & $287.0 \pm 382.3(24)$ & 0.00 \\
\hline Iron $(\mathrm{mg})$ & $8.9 \pm 5.6(90)$ & $9.7 \pm 5.5(97)$ & $7.3 \pm 4.6(74)$ & 0.02 \\
\hline Zinc (mg) & $6.6 \pm 4.5^{\mathrm{ab}}(127)$ & $6.6 \pm 4.6^{\text {ba }}(126)$ & $6.1 \pm 5.0(118)$ & 0.00 \\
\hline Vitamin C (mg) & $26.8 \pm 37.2(59)$ & $30.3 \pm 41.6(68)$ & $39.0 \pm 53.9(87)$ & 0.00 \\
\hline Vitamin B1 (mg) & $0.7 \pm 0.5^{\mathrm{ab}}(60)$ & $0.7 \pm 0.5^{\text {ba }}(59)$ & $0.7 \pm 0.5(62)$ & 0.00 \\
\hline Vitamin B2 (mg) & $0.7 \pm 0.5(59)$ & $0.7 \pm 0.5(63)$ & $0.6 \pm 0.4(51)$ & 0.00 \\
\hline Vitamin B3 (mg) & $14.1 \pm 13.5(99)$ & $11.2 \pm 9.5(78)$ & $11.9 \pm 12.3(83)$ & 0.01 \\
\hline Vitamin B6 (mg) & $0.8 \pm 0.5^{\mathrm{abc}}(58)$ & $0.8 \pm 0.5^{\text {bac }}(59)$ & $1.0 \pm 0.9^{\mathrm{cba}}(67)$ & 0.06 \\
\hline Folate $(\mu \mathrm{g})$ & $161.7 \pm 130.4(40)$ & $185.0 \pm 142.8(45)$ & $137.4 \pm 119.1(34)$ & 0.00 \\
\hline Vitamin B12 $(\mu \mathrm{g})$ & $3.1 \pm 6.0(129)$ & $2.2 \pm 4.8(89)$ & $2.6 \pm 5.7(106)$ & 0.00 \\
\hline Vitamin $\mathrm{A}(\mu \mathrm{g})$ & $642.4 \pm 886.1(124)$ & $619.2 \pm 788.4(119)$ & $568.7 \pm 568.3(110)$ & 0.00 \\
\hline
\end{tabular}

SD: Standar Deviation; a,b,c no difference between two clusters, using Mann Whitney test; $p<0.05$, significantly differences between three clusters using Kruskall Wallis test

cluster regions have different spatial dimension and vector direction with the position of each group that is far and opposite each other, thereby the three groups have a clearer distinction to each other. Besides that, biplot visualization also shows the formation of three spaces of most prominent food groups as the main characteristics in each cluster region. The main characteristics are as follows: cereals and animal source foods in Cluster-1 region; pulses, oil and fat, oily seeds, and other foods in Cluster-2 region; tubers, fruits, and vegetables in Cluster- 3 region.

The three distinct features of the food are generally far apart (forming an obtuse angle) with each other with different vector directions. It means that the tendency of intake among these food groups is clearly different from each other. Tubers, as well as fruits and vegetables, have obtuse angles and vector directions opposite to sugar, pulses, oil and fat, oily seeds, cereals and animal source foods. It implies that the intakes of these food groups have negative associations. The lower the intake of tubers, fruits and vegetables, the higher the intake of sugar, pulses, oil and fat, oily seeds, cereals as well as animal source food. It indicates that the balance of intake proportion of each food group needs to be considered to minimize the dominance of one or certain food groups. Meanwhile, intake of cereals and animal source foods form acute angles $\left(<90^{\circ}\right)$ with pulses, fat and oil, oily seeds and other food groups with parallel vector directions, which means that the intakes of these food groups have a similar tendency; i.e. the high intake of cereals and animal source foods is in line with the high intake of these food groups. It also means that intakes of pulses, fat and oil, oily seeds, and other food groups complement the intakes of cereals and animal source foods.

\section{Nutrient intake and adequacy}

Table 2 presents the description of nutrient intake and adequacy level of the foods consumed by the subjects every day among WRA in three clusters. Energy, protein, and carbohydrate intakes in the three clusters had reached a normal adequacy level $(\geq 90 \%)$. Fat intake in Clusters-1 and 2 belonged to the normal category, while the one in Cluster-3 belonged to extremely inadequate category $(<70 \%)$.

Micronutrients such as calcium, zinc, vitamin B1, vitamin B2, vitamin B6, and folate were a potential problem nutrient $(\leq 77 \%$ of RDA) in the three clusters. Vitamin C only reached normal adequacy withiin Cluster-3. In contrast, iron intake was adequate among WRA in Clusters-1 and 2. As described in Table 3, inadequacy of micronutrients were potentially due to low intake of the food sources containing the micronutrients.

WRA in Cluster-3 had the largest number of nutrients below normal adequacies compared to Clusters-1 and 2. Calcium, vitamin C, vitamin B1, B2, B6, and folic acid could not meet the normal adequacies of the subjects in Clusters-1 and 2. Meanwhile, WRA in Cluster-3 only met the normal adequacies of energy, protein, carbohydrates, zinc, vitamin A, B3, and B12. 
Humayrah et al.

Table 3. The top three main food sources nutrients among WRA in three clusters

\begin{tabular}{|c|c|c|c|c|c|}
\hline \multicolumn{2}{|l|}{ Cluster-1 } & \multicolumn{2}{|l|}{ Cluster-2 } & \multicolumn{2}{|l|}{ Cluster-3 } \\
\hline Food types & $\%$ & Food types & $\%$ & Food types & $\%$ \\
\hline \multicolumn{6}{|l|}{ Energy } \\
\hline Cereals (rice \& corn) & 52 & Cereals (rice \& corn) & 43 & Cereals (rice \& corn) & 44 \\
\hline Cooking oil & 9 & Cooking oil & 13 & Fishes & 8 \\
\hline Flour \& products & 9 & Flour \& products & 11 & Other tubers & 8 \\
\hline \multicolumn{6}{|l|}{ Protein } \\
\hline Fishes & 37 & Cereals (rice \& corn) & 29 & Fishes & 42 \\
\hline Cereals (rice \& corn) & 35 & Soybean \& products & 21 & Cereals (rice \& corn) & 30 \\
\hline Poultry/small mammals & 9 & Fishes & 14 & Poultry/small mammals & 4 \\
\hline \multicolumn{6}{|l|}{ Fat } \\
\hline Cooking oil & 31 & Cooking oil & 42 & Cooking oil & 21 \\
\hline Poultry/small mammals & 13 & Poultry/small mammals & 14 & Cereals (rice \& corn) & 7 \\
\hline Flour \& products & 8 & Soybean \& products & 10 & Other fats & 6 \\
\hline \multicolumn{6}{|l|}{ Carbohydrate } \\
\hline Cereals (rice \& corn) & 75 & Cereals (rice \& corn) & 59 & Cereals (rice \& corn) & 63 \\
\hline Flour \& products & 9 & Flour \& products & 8 & Tubers \& products & 12 \\
\hline Sugar & 5 & Sugar & 5 & Vitamin-rich tubers & 5 \\
\hline \multicolumn{6}{|l|}{ Calcium } \\
\hline Processed meat & 7 & Soybean \& products & 13 & Fishes & 6 \\
\hline Fishes & 6 & Processed meat & 3 & Green leavy vegetables & 4 \\
\hline Soybean \& products & 4 & Green leavy vegetables & 2 & Other vegetables & 3 \\
\hline \multicolumn{6}{|l|}{ Iron } \\
\hline Cereals (rice \& corn) & 18 & Soybean \& products & 21 & Cereals (rice \& corn) & 16 \\
\hline Fishes & 13 & Flour \& products & 16 & Fishes & 13 \\
\hline Flour \& products & 13 & Cereals (rice \& corn) & 15 & Green leavy vegetables & 7 \\
\hline \multicolumn{6}{|l|}{ Zinc } \\
\hline Cereals (rice \& corn) & 50 & Cereals (rice \& corn) & 41 & Cereals (rice \& corn) & 43 \\
\hline Other vegetables & 14 & Soybean \& products & 20 & Other vegetables & 23 \\
\hline Flour \& products & 13 & Flour \& products & 16 & Fishes & 14 \\
\hline \multicolumn{6}{|l|}{ Vitamin C } \\
\hline Green leavy vegetables & 21 & Vitamin-rich fruits & 21 & Vitamin-rich tubers & 77 \\
\hline Vitamin-rich fruits & 13 & Green leavy vegetables & 20 & Green leavy vegetables & 35 \\
\hline Vitamin-rich vegetables & 10 & Vitamin-rich vegetables & 10 & Vitamin-rich fruits & 11 \\
\hline \multicolumn{6}{|l|}{ Vitamin A } \\
\hline Cooking oil & 50 & Cooking oil & 71 & Vitamin-rich tubers & 57 \\
\hline Fishes & 13 & Poultry/small mammals & 13 & Cooking oil & 23 \\
\hline Poultry/small mammals & 13 & Vitamin-rich vegetables & 10 & Green leavy vegetables & 14 \\
\hline
\end{tabular}

\section{Nutritional characteristic types of each cluster}

Cluster-1. Based on Tables 2 and 3, it could be concluded that WRA in Cluster- 1 had high intake of cereals and animal source foods characteristics. The high intake of cereals was in line with the high intake of energy, carbohydrates, and zinc. Intake of animal source foods in this cluster was also in line with the adequacy of protein, fat, iron, vitamin $\mathrm{A}$, vitamin $\mathrm{B} 3$, and vitamin B12 intakes.
Subjects in this cluster had the lowest intake of vitamin $\mathrm{C}$ and vitamin B6 than other clusters. Their main sources of vitamin B6 derived from pulses, cereals, fruits, and vegetables. However, cereals became the highest vitamin B6 contributor food in this cluster that only reached approximately $20 \%$ of daily adequacy, while others food only reached less than $10 \%$ of adequacy (Table 3 ). This result was similar to vitamin $\mathrm{C}$ intake, in which the 
WRA's intake of fruits and vegetables in this cluster was in the second order (Table 3 ) but the amount consumed was not much different from Cluster-2. In addition, intake of tubers was the lowest compared to another cluster, even though tubers were the food sources of vitamin C.

Calcium, vitamin B1, B2, and folic acid adequacies in Cluster-1 went into second place (Table 3) but still did not reach the normal adequacies. Total portion of food source intake that could fulfill the adequacy of these nutrients was low in this cluster. Animal source foods, pulses, green leavy vegetables, or fruits were rich in vitamin B-complex and calcium, but the highest food sources could only meet less than $20 \%$ of the daily requirements (Table 2 ).

Cluster-2. Intake of pulses, fat and oil, oily seeds, sugar, and others food in the WRA in Cluster-2 were the highest. WRA's intake of animal source foods in this cluster was the lowest compared to the other two clusters, but iron and zinc intakes in Cluster-2 could be complemented by the intake of soybean and products (Tables 1, 2 , and 3). Soybean and products were the sources of iron and calcium only for WRA in Cluster-2. Whereas, soybean are food rich in iron and calcium that can be considered as milk substitute (Mazumder \& Begum 2016; Haron et al. 2010). Besides that, the high intake of oil, fat and oily seeds were in line with fat intake, thereby the percentage of fat adequacy in this cluster was the highest compared to the other two clusters. Cooking oil contributed more than $40 \%$ of fat adequacy (Tables 2 and 3 ).

Meanwhile, folate adequacy in this cluster was in the first place but still below the normal adequacy, because the highest food sources of folate only reached approximately $10 \%$ of adequacy that was contributed by flour and products. In addition, fruits and vegetables intakes were the lowest compared to the other two clusters (Table 1). The low intake of fruits and vegetables also had an impact on the inadequacy of vitamin $\mathrm{C}, \mathrm{B} 1, \mathrm{~B} 2$, and B6 intakes in this cluster (Tables 1 and 3). Then, intake of animal source foods in this cluster was the lowest, along with the low intake of vitamin B3 and B12 (Tables 1 and 3). The contribution of animal source foods (fishes) to vitamin B3 in this cluster was the lowest compared to Clusters- 1 and 3 (Table 2).

Cluster-3. Calcium, iron, vitamin B2, and folate adequacies were the lowest in WRA in Cluster-3 because the highest food sources of these nutrients could only fulfill less than $20 \%$ of the daily requirements (Table 2). Besides that, WRA's intake of pulses in this cluster was the lowest compared to other clusters (Table 1 ), whereas pulses such as soybean and its processed products could also complement the daily requirements of calcium, iron, vitamin B2 and folate as in Clusters-1 and 2. Soybean and its processed products were not included as the three highest food sources of these nutrients.

Meanwhile, this cluster had the highest percentage of vitamin $\mathrm{C}, \mathrm{B} 1$, and $\mathrm{B} 6$ adequacies than other clusters, although not reaching the normal adequacies (Table 2). The high intake of tubers, fruits, and vegetables also contributed approximately $15-50 \%$ of daily adequacies of vitamin $\mathrm{C}, \mathrm{B} 1$, and $\mathrm{B} 6$ in this cluster. In addition, tubers were also the highest vitamin A contributor (Table 3). The intake of tubers in this cluster also contributed more than $15 \%$ of carbohydrate adequacy, and it was the highest contribution compared to the other two clusters after cereals such as rice and corn (Tables 2 and 3 ).

Animal source foods consumed by WRA in Cluster-3 were dominated by fishes, which were also the main food sources of protein (Tables 1 and 2). The high intake of fishes also affected the high adequacy of vitamin B3 and B12 in this cluster (Table 2). On the other hand, WRA's fat adequacy percentage in this cluster was the lowest compared to Clusters- 1 and 2 because cooking oil as the highest source of fat only contributed for about $20 \%$ of the daily fat adequacy, while other sources of fat were derived from plantbased foods (cereals) that only contributed to less than $10 \%$ of daily fat adequacy. Animal source foods such as fishes were not the fat source in this cluster (Tables 2 and 3).

Overall, the results of this study showed that FCP of WRA in the three clusters were still dominated by staple foods such as cereals, oil, and fat. Energy contribution among WRA in three clusters are from cereals (rice and corn) while most of other energy food sources were contributed by cooking oil and fortified cereals (wheat flour such as noodles). Beside that, the highest source of fat and vitamin $\mathrm{A}$ in three clusters derived from cooking oil (Table 3). The staple foods of WRA in three clusters were high in calorie but low in other nutrients, thereby these foods could not guarantee the adequacies of all nutrients, especially micronutrients. Staple food intake needs to be balanced with intake of various other nutrient-dense foods such as animal source foods, tubers, fruits, and vegetables.

Based on this study, cooking oil was the highest vitamin A contributor in clusters 1 and 2 while was the second contributor in cluster-3. In cluster-2, the cooking oil even contributed for 
more than $70 \%$ of vitamin A adequacy (Table 3). The high adequacy of vitamin A from cooking oil was related to food fortification program in Indonesia, as an effort to overcome the deficiency of vitamin A (Martianto 2012; Hariyadi 2011). However, it should be considered that cooking oil also contributes to a high fat intake which could caused to obesity. Therefore, the subjects should not only rely on the cooking oil to fulfill the daily requirement of vitamin $\mathrm{A}$ but also from high fiber and others vitamins A rich-foods. For example, WRA in Cluster-3 was able to fulfill their daily requirements of vitamin A from tubers.

Meta-analysis study on obese adult subjects by Stelmach-Mardas et al. (2016) indicated that low-calorie foods such as fruits and vegetables could decrease body weight because they could provide a longer satiety effect than high-calorie foods. In addition, Zheng et al. (2016) showed that portion size and types of foods determined the calorie intake and implicated the incidence of obesity among adults in Australia. High calorie foods consumed in large portions were slow satiated, thereby causing excess calorie intake.

This study also showed that the foods contributing to vitamin and mineral adequacies were more varied in types than the ones contributing to macronutrient adequacy (Table $3)$. This finding also showed that micronutrient source foods were consumed only by less than $30 \%$ of subjects. It was due to the types of macronutrient rich food that were the staple foods, commonly consumed in large quantities by WRA. While food sources of micronutrients consumed were as the complementary of staple foods or as a snack. These results were also in agreement with the previous studies indicating that food intake of Indonesian WRA was still dominated by staple food, thereby shifting the intake of other food groups (Rahmawati et al. 2015; Perdana et al. 2014).

FAO (2012) has introduced and promoted the concept of sustainable dietary patterns associated with food biodiversity in accordance with the carrying capacity of the region. According to Caspia et al. (2012) and Kearney (2010), FCP of the population reflects the food availability and affordability in the region. Tucker (2010) said that the clustering study which was a part of FCP research that has great potential for use in nutrition policy. The result of this study is an approach to understand the similarity of dietary pattern characteristics of WRA in three types of regions in Indonesia. Through the understanding, the potential of food that can support the nutrient adequacies of WRA in the region can be identified, so that it becomes a consideration in the food and nutrition programs.

\section{CONCLUSION}

There are three clusters of FCP of WRA in Indonesia. The first type was FCP with high intake of cereals and animal source foods but low intake of pulses, tubers, as well as fruits, and vegetables. The second type was FCP with high intake of pulses, oil and fat, oily seeds, sugar, and other foods but low intake of animal source foods, fruits, and vegetables. The third type was FCP with high intake of tubers, fruits, and vegetables but low intake of animal source foods, pulses, oil and fat, as well as oily seeds.

In order to improve the nutrient adequacy of WRA, this study suggests that WRA in Cluster-1 to increase intake of pulses, tubers, fruits, and vegetables to prevent vitamin B6 and $\mathrm{C}$ deficiencies. Then, WRA in Cluster-2 should be aware of the risks of excess fat from high-fat foods, and proposed to increase intake of animal source foods, fruits, and vegetables to reduce the risk of vitamin B1, B3, and B12 deficiencies. While for WRA in Cluster-3 should increase intake of high-quality animal source foods and pulses to prevent fat, calcium, iron, vitamin B2 and folate deficiencies. This study can be considered by the food and nutrition policy makers to arrange food consumption recommendations based on the type of regional FCP as well as the adequacy of nutrients which not only focuses on macronutrients but also prioritized on the micronutrients source foods.

\section{ACKNOWLEDGEMENT}

We would like to express our gratitude to the Indonesian Endowment Fund for Education (LPDP) of Ministry of Finance, Republic of Indonesia that has sponsored the funding of this study through Indonesian Education Scholarship (BPI). We would like to thank National Institute of Health Research and Development, Ministry of Health of Republic of Indonesia and Food Security Agency, Ministry of Agriculture of Republic of Indonesia that have been pleased to provide data access for this study. The authors has no conflict of interest.

\section{REFERENCES}

Arifin EN, Ananta A, Utami DRWW, Handayani NB, Pramono A. 2015. Quantifying 
Indonesia's ethnic diversity. Asian Population Studies 11(3):233-256. http:// dx.doi.org/10.1080/17441730.2015.10906 92.

Babu SC, Gajanan SN, Sanyal P. 2014. Food Security, Poverty and Nutrition Policy Analysis: Statistical Methods and Applications. Oxford: Academic Press.

Bailey RL, Gutschall MD, Mitchell DC, Miller CK, Lawrence FR, Smiciklas-Wright H. 2006. Comparative strategies for using cluster analysis to assess dietary patterns. J Am Diet Assoc. 106(8):1194-1200.

Branca F, Piwoz E, Schultink W, Sullivan LM. 2015. Nutrition and health in women, children, and adolescent girls. BMJ 351:27-31. doi: http://dx.doi.org/10.1136/ bmj.h4173.

Cahyaningsih R. 2008. Analysis of food consumption pattern in West Java Province [thesis]. Bogor: IPB University.

Caspia CE, Sorensena G, Subramaniana SV, Kawachia I. 2012. The local food environtment and diet: A systematic review. Health \& Place 18(5): 1172-1187.

Civitello L. 2011. Cuisine and Culture, $3^{\text {rd }}$ Edition. Hoboken. New Jersey: John Willey \& son, Inc.

Dachlan D, Suhab S. 2014. Pembangunan Kawasan Indonesia Timur dalam Konteks Kekinian Indonesia. Makassar: Puslitbang Kebijakan dan Manajemen Lembaga Penelitian dan Pengabdian Masyarakat, Universitas Hasanuddin.

Everitt BS, Landau S, Leese M, Stahl D. 2011. Cluster Analysis: $5^{\text {th }}$ Edition. London (UK): John Wiley \& Sons, Ltd.

[FAO] Food and Agriculture Organization of the United Nations. 2006. The state of food insecurity in the world. Washington DC (US): FAO. [Accessed 21 February 2015]

[FAO] Food and Agriculture Organization of the United Nations. 2012. Sustainable diets and biodiversity. Rome: FAO. [Accessed 21 February 2015]

[FAO] Food and Agriculture Organization of the United Nations. 2013. Food composition table for Indonesia. Available at: www. fao.org/fileadmin/templates/food composition/documents/FCT SMILING PROJECT_ASIA/D3_5a_SMILING FCT_Indonesia_070813_protected.xlsx

Gibson Rosalind S. 2005. Principles of Nutritional Assessment: $2^{\text {nd }}$ Edition. Dunedin: Oxford University Press.
Hardinsyah. 2007. Review faktor determinan keragaman konsumsi pangan. J Gizi Pangan 2(2):55-74.

Hardinsyah, Riyadi H, Napitupulu V. 2012. Kecukupan energi, protein, lemak dan karbohidrat. https:// www.researchgate.net/profile/Hadi Riyadi/publication/301749209 KECUKUPAN ENERGI PROTEIN LEMAK_DAN $\overline{\mathrm{N}}$ KARBOHIDRAT/ links/57254d4b08aef9c00b846b0a/ KECUKUPAN-ENERGI-PROTEINLEMAK-DAN-KARBOHIDRAT.pdf. [Accessed 28 August 2015].

Hargrove JL. 2006. History of the calorie in nutrition. J Nutr 136(12):2957-2961.

Hariyadi. 2011. Vitamin A fortification technology on palm oil. Proceedings of Workshop on Vitamin A Fortification on Palm Oil Palm. Bogor: Seafast IPB. Available at : http:// seafast.ipb.ac.id/publication/presentation/ teknologi-fortifikasi-vit-A\%20padaminyak-sawit.pdf. [Accessed 16 March 2011].

Haron H, Shahar S, O'Brien KO, Ismail A, Kamaruddin N, Rahman SA. 2010. Absorption of calcium from milk and tempeh consumed by postmenopausal Malay women using the dual stable isotope technique. Int J Food Sci Nutr 61(2):125137.

Henry, CJK. 2005. Basal metabolic rate studies in humans: measurement and development of new equations. Public Health Nutr: 8(7A): 1133-1152. doi: 10.1079/PHN2005801.

Hines WR. 2013. Food preparation methods and regional identification in Indonesia [Thesis]. Utah: The University of Utah.

Kearney J. 2010. Food consumption trend and driver. Phil Trans R Soc B 365:2793-2807.

[MoH] Ministry of Health Republic of Indonesia. 2013. Indonesian basic health research 2013. National Institute of Health Research and Development, Ministry of Health, Republic of Indonesia. http:// www.depkes.go.id/resources /download/ general/Hasil\%20Riskesdas\%202013.pdf. [Accessed 20 June 2015].

[MoH] Ministry of Health Republic of Indonesia. 2014. Total Diet Study 2014. National Institute of Health Research and Development. Ministry of Health, Republic of Indonesia.

$[\mathrm{MoH}]$ Ministry of Health Republic of Indonesia. 2016. General Guidelines: Healthy 
Indonesia Program with Family Approach. Ministry of Health Republic of Indonesia.

[MoA] Ministry of Agriculture, Republic of Indonesia. 2015. Forum group discussion of harmonization of food consumption. Ministry of Agriculture internal meeting, 17-18 Feb 2015 [unpublished]. Jakarta: Ministry of Agriculture.

[MoA] Ministry of Agriculture Republic of Indonesia. 2016. Directory Book of Food Consumption Development Indonesia. Food Security Agency. Ministry of Agriculture of Republic of Indonesia

Lassi ZS, Salam RA, Das JK, Wazny K, BhuttaZA. 2015. An unfinished agenda on adolescent health: opportunities for interventions. Seminar in perinatology 39(5):353-360. doi: 10.1053/j.semperi.2015.06.005.

Latifah S. 2016. Obesogenic environment mapping among adult aged 19-49 years in district municipal level in Indonesia cluster analysis [Thesis]. Jakarta: University of Indonesia.

Martianto. 2012. Food fortification for prevention and prevention of micronutrient deficiencies. Bogor: IPB University.

Mattjik AA, Sumertajaya I. 2011. Book of Multivariate Analysis. Bogor: IPB Press.

Mazumder MAR, Begum AA. 2016. Soymilk as source of nutrient for malnourished population of a developing country: A review. International Journal of Advanced Scientific and Technical Research 5(6):192-203.

Mulyana D, Zubair A. 2015. Intercultural communication competence developed by Chinese in communicating with Malays in Bangka Island, Indonesia. SinoUS English Teaching. 12(4):299-309, doi:10.17265/1539-8072/2015.04.009.

Perdana SM, Hardinsyah, Damayanthi E. 2014. Alternative indeks gizi seimbang untuk penilian mutu gizi konsumsi pangan wanita dewasa Indonesia. J Gizi Pangan 9(1):43-50.

[Persagi] Persatuan Ahli Gizi Indonesia. 2013. Food Composition Table of Indonesia. Jakarta: PT Elex Media Komputindo.

Prihatini S, Jahari AB. 2010. Kontribusi golongan bahan makanan terhadap konsumsi energi dan protein rumahtangga di Indonesia. PGM 33(1):30-41.
Purwadaria H.K, Fardiaz D, Kardono LBS, McElhatton A. 2016. Tempe From Traditional to Modern Practices. In: McElhatton A, El Idrissi M. (eds) Modernization of Traditional Food Processes and Products. Integrating Food Science and Engineering Knowledge Into the Food Chain vol 11. Boston: Springer.

Rahmawati R, Hardinsyah H, Roosita K. 2015. Pengembangan indeks gizi seimbang untuk menilai kualitas gizi konsumsi pangan remaja (13-15 tahun) di Indonesia. Jurnal MKMI 11(3): 160-167.

Ren J, Chung JE, Stoel L, Xu Y. 2011. Chinese dietary culture influences consumers' intention to use imported soy-based dietary supplements: an application of the theory of planned behaviour. International Journal of Consumer Studies 35(6): 661-669.

Stelmach-Mardas M, Rodacki T, DobrowolskaIwanek J, Brzozowska A, Walkowiak J, Wojtanowska-Krosniak A, Zagrodzki $\mathrm{P}$, Bechthold A, Mardas M, Boeing $\mathrm{H}$. 2016. Link between food energy density and body weight changes in obese adults. Nutrients 8(4):229.

Santoso S. 2010. Statistik Multivariant. Jakarta: Elex Media Komputindo.

Situngkir H, Maulana A, Mauludy R. 2015. A portrait of diversity in Indonesian traditional cuisine. SSRN 2703706 http://papers.ssrn.com/sol3/papers. cfm?abstract id $=2703706$. [Acessed 22nd August 2016].

Shurtleff W, Aoyagi A. 2011. History of Tempeh and Tempeh Products (1815-2011): Extensively Annotated Bibliography and Sourcebook. Lafayette: Soyinfo Center.

Tucker KL. 2010. Dietary patterns, approaches, and multicultural perspective. Appl Physiol Nutr Metab 35(2): 211-218.

[WHO/FAO] World Health Organization and Food and Agriculture. 2004. Vitamin and Mineral Requirements in Human Nutrition. Roma: Food and Nutrition Division FAO.

Zheng M, Wu JHY, Louie JCY, Flood VM, Gill T, Thomas B, Cleanthous X, Neal B, Rangan A. 2016. Typical food portion sizes consumed by Australian adults: results from the 2011-2012 Australian National Nutrition and Physical Activity Survey. Sci Rep 6(2016):19596. 